\title{
Rekonstrukcja sieci osadniczej w serii „Atlas historyczny Polski. Mapy szczegółowe XVI wieku”
}

\section{Marek Słoń}

Jednym z głównych zadań wskazanej w tytule serii jest kartograficzna rekonstrukcja sieci osadniczej. Wstępne założenia projektu sformułował w 1880 r. Stanisław Smolka'. Systematyczną realizację jego wizji udało się jednak wdrożyć dopiero w drugiej połowie następnego stulecia. Decydujące było powołanie Zakładu Atlasu Historycznego w Instytucie Historii PAN (1953) i ustalenie w latach 60. zasad edycji serii „Mapy szczegółowe XVI wieku”. Do tej pory ukazało się pięć tomów obejmujących osiem województw ${ }^{3}$. Doświadczenia zebrane podczas sześćdziesięciu lat pracy nad tym dziełem są dobrą podstawą do ogólnej refleksji metodologicznej.

Program serii obejmuje osiem podstawowych informacji na temat każdej zidentyfikowanej osady. Są one prezentowane w dwóch formach: kartograficznej i indeksowej. Żadna nie zawiera kompletu danych. Na mapie nie zostały uwzględnione osady niezlokalizowane oraz odmianki nazw, natomiast w indeksie brakuje wiadomości o wielkości danej miejscowości, a spośród pełnionych przez nią funkcji centralnych uwzględniono tylko siedzibę parafii. Niektóre z tych informacji, np. istnienie osady, mają charakter logiczny (prawda/fałsz) lub tekstowy (nazwa), ale większość odwołuje się do zamkniętej listy kategorii.

Na niektóre pytania atlas daje więcej niż jedną odpowiedź: osada mogła mieć dwie nazwy, używane $\mathrm{z}$ różną częstotliwością, należeć do

1 S. Smolka, 0 przygotowawczych pracach do geografii historycznej Polski, oprac. J. Kurowiak, wstęp M. Filipowicz, „Studia Geohistorica”, 1, 2013, s. 8-13. Edycja pierwotna: Pamiętnik pierwszego Zjazdu Historycznego Polskiego imienia Jana Długosza odbytego w Krakowie w czterechsetną rocznicę jego śmierci, Kraków 1881, s. 133-137 (Scriptores rerum Polonicarum, 6).

2 H. Rutkowski, Atlas historyczny Polski, w: Towarzystwo Naukowe Warszawskie. Sto lat działalności, red. E. Wolniewicz-Pawłowska, W. Zych, Warszawa 2009, s. 121-122; B. Konopska, Polskie atlasy historyczne. Koncepcje i realizacje, Warszawa 1994, s. 128-132; W. Pałucki, Przed- różnych właścicieli, pełnić kilka funkcji centralnych, być przedzielona granicą świecką lub kościelną. Jeśli atlas uwzględnia takie możliwości, charakter tej informacji został tu uznany za mieszany. W odniesieniu do charakteru osady zasadniczo przyjęto podawanie tylko jednej możliwości: jeśli nawet we wsi był młyn lub karczma o własnej nazwie, to były one uznawane za obiekty stanowiące jej część. Od tej zasady są jednak wyjątki. Opactwa, zamki i kopalnie oznaczane są na mapie dodatkowymi sygnaturami opatrzonymi nazwą własną wspólną z oznaczoną obok wsią lub miastem.

Większość miejscowości została względnie jednoznacznie zlokalizowana przestrzennie, jednak istnieje znaczna liczba przypadków, w których ustalenie to ma jedynie charakter hipotezy (nie jest pewna identyfikacja obiektu znanego z przekazów kartograficznych z wymienionym w XVI-wiecznych źródłach) lub znacznego przybliżenia (błąd przypuszczalnie przekracza $1 \mathrm{~km}$ ). Trzeba jednocześnie zaznaczyć, że pewien stopień przybliżenia dotyczy wszystkich miejscowości, a wynika on z przyjętej skali mapy i użytych na niej symboli. W odniesieniu do nazw mamy do czynienia nie tylko z poświadczonym funkcjonowaniem dwóch różnych form lub niepewnym przyporządkowaniem co najmniej jednej z nich. Czasem zdarzały się przypadki, gdy do dwóch (wyjątkowo nawet trzech, np. Zawisty-Zuzołka w powiecie nurskim) sąsiadujących ze sobą osad odnosi się para lub gru-

mowa, w: S. Wojciechowski, Województwo lubelskie w drugiej połowie XVI wieku, (Atlas historyczny Polski. Mapy szczegółowe XVI wieku [dalej: Atlas], 3) Warszawa 1966, s. 7-12.

3 S. Wojciechowski, Województwo lubelskie, Warszawa 1966 (Atlas, 3); Mazowsze w drugiej połowie XVI wieku, red. W. Pałucki, Warszawa 1973 (Atlas, 7); Województwo sandomierskie w drugiej połowie XVI wieku, red. W. Pałucki, Warszawa 1993 (Atlas, 2); Województwo sieradzkie i województwo tęczyckie w drugiej połowie XVI wieku, red. H. Rutkowski, Warszawa 1998 (Atlas, 5); Województwo krakowskie w drugiej potowie XVI wieku, red. H. Rutkowski, Warszawa 2008 (Atlas, 1). 
Tab. 1. Zakres treści osadniczej na mapie i w indeksie

\begin{tabular}{|c|c|c|c|c|c|}
\hline Lp. & Temat informacji & Mieszane & Hipoteza & Przybliżenie & Prezentacja \\
\hline 1 & istnienie osady & nie & nie & nie & indeks i cz. mapa $^{4}$ \\
\hline 2 & lokalizacja & nie & tak & tak & mapa i indeks \\
\hline 3 & nazwa & tak & tak & tak & indeks i cz. mapa $^{5}$ \\
\hline 4 & charakter osady & nie & nie & nie & mapa i indeks \\
\hline 5 & wielkość & nie & nie & tak & mapa \\
\hline 6 & własność & tak & nie & nie & mapa i indeks \\
\hline 7 & funkcje centralne & tak & nie & nie & mapa i cz. indeks ${ }^{6}$ \\
\hline 8 & przynależność administracyjna & tak & tak & nie & indeks i cz. mapa \\
\hline
\end{tabular}

Źródło: opracowanie własne na podstawie serii „Atlas historyczny Polski. Mapy szczegótowe XVI w." cz. - częściowo

pa nazw, lecz nie da się ich jednoznacznie przyporządkować. Charakter każdej miejscowości: wsi, miasta, młyna itd. zawsze oznaczony jest jednoznacznie, choć niejednokrotnie występują przypadki graniczne (np. nie w pełni udana lokacja miejska) czy słabo udokumentowane i w konsekwencji hipotetyczne. Podobnie jest z wielkością osady, choć tu z zasady stosowane jest znaczące przybliżenie. Potencjał demograficzny danej miejscowości określany jest przez przyporządkowanie do jednej z kategorii obejmujących szerokie przedziały liczbowe. Nie sygnalizuje się natomiast np. zmiany w czasie lub braku pewności poczynionych ustaleń. Własność zawsze określana jest jednoznacznie, lecz z uwzględnieniem przypadków mieszanych, gdy jedna osada była podzielona między dwóch lub więcej panów należących do różnych stanów. Podobnie ma się rzecz z funkcjami centralnymi: na mapie i w indeksie nie znajduja odzwierciedlenia wątpliwości w odniesieniu do stołeczności niektórych ośrodków, natomiast oznaczone jest łączenie takiej roli np. w administracji państwowej i kościelnej. Umieszczenie

\footnotetext{
4 Mapa nie obejmuje osad niezlokalizowanych.

5 Na mapie nie ma nazw osad o lokalizacji wiązanej oraz niezlokalizowanych.

6 W indeksie widnieje jedynie informacja o najczęściej spotykanej funkcji centralnej - siedzibie parafii.

7 Mapa nie uwzględnia wątpliwej przynależności osady, podaje jedynie informację zgodną z wariantem uznanym przez autorów za bardziej prawdopodobny.
}

na mapie symbolu osady dokładnie na granicy może oznaczać zarówno niepewną, jak i podzieloną przynależność do jednostki terytorialnej. W indeksie jest to ujęte precyzyjnie, a w przypadkach hipotetycznych podane są oba warianty ze wskazaniem bardziej prawdopodobnego ${ }^{8}$.

Wydane dotąd tomy objęly ok. 15000 miejscowości. W takiej masie materiału znalazła się oczywiście znaczna liczba przypadków trudnych do zaklasyfikowania w różnych aspektach. Problemy wynikają przede wszystkim z trzech okoliczności. Pierwsza to zmiany w czasie. Atlas odnosi się do całego półwiecza (1551-1600), co pozwala na wykorzystanie stosunkowo szerokiej podstawy źródłowej i uwzględnienie wzmianek o miejscowościach i ich statusie $\mathrm{z}$ różnych lat. W odniesieniu do zjawisk, które mogą być interpretowane jako rozwój (np. liczba mieszkańców, status miasta), przyjmuje się wartość maksymalną. W innych - jak choćby przynależność terytorialna czy rodzaj własności - za punkt odniesienia uznaje się końcową datę tego okresu. Zabiegi te nie rozwiązują wszystkich problematycznych przypadków, w których często

\footnotetext{
8 W. Pałucki, Przedmowa, s. 10; S. Wojciechowski, Województwo lubelskie, s. 29-30, 36; H. Rutkowski, Lokalizacja miejscowości, w: Mazowsze, s. 64-71; K. Pacuski, Lokalizacja miejscowości, w: Województwo sandomierskie, s. 71-75; K. Chłapowski, Lokalizacja miejscowości, w: Województwo sieradzkie, s. 42-47; tenże, Lokalizacja miejscowości, w: Województwo krakowskie, s. 64-66 oraz wprowadzenie do indeksów w kolejnych tomach serii.
} 
nakładają się dwa kolejne aspekty. Drugi spośród nich to wartości marginalne. Przyjmujemy np. zasadę, że za wieś uznajemy osadę, w której potwierdzona jest obecność kmieci lub zagrodników. Jeśli jednak miejscowość konsekwentnie określana jest jako folwark, a raz pojawia się w niej jeden zagrodnik, to czy właściwe jest oznaczenie jej po prostu jako wieś? Wreszcie trzeci problem to niepełne dane. Poddajemy ocenie i kategoryzacji nie realia tamtych czasów, lecz naszą wiedzę na ich temat, zwykle skromną, wręcz szczątkową. Zachowane przekazy nie odzwierciedlają zresztą rzeczywistości wprost, lecz jedynie pośrednio i mają różny stopień wiarygodności. Np. podstawowe dla nas źródło, jakim są rejestry poborowe, nie informuje wcale o istnieniu osady, lecz jedynie o tym, że w danej księdze odnotowano pochodzące od niej wpłaty. Można więc z dużym prawdopodobieństwem przyjąć, że podatek rzeczywiście uiszczono. Nie mamy jednak pewności, że pisarz nie pomylił nazwy miejscowości. Pojedynczy spis nie daje także żadnych podstaw do wnioskowania ex silentio, ponieważ funkcjonująca wieś mogła być $\mathrm{z}$ różnych przyczyn pominięta $\mathrm{w}$ rejestrze. Jednocześnie brak oznaczenia na naszej mapie miejscowości, która w późniejszych stuleciach dowodnie istniała, może być interpretowany jako stwierdzenie jej nieobecności w XVI w.

Mimo wskazanych powyżej trudności seria „Mapy szczegółowe XVI wieku” została dobrze przyjęta $\mathrm{w}$ środowisku historyków, ma opinię publikacji użytecznej i rzetelnej ${ }^{10}$. Zawdzięcza ją kilku elementom, które stopniowo wprowadzano do programu prac atlasowych.

Pierwszy - obecny od samego początku nie tylko edycji, lecz jej ogólnej idei, sformułowanej na pierwszym zjeździe historyków w Krakowie w 1880 r. - to wybór właściwego przedmiotu opracowania. 2. poł. XVI w. charakteryzuje się

\footnotetext{
${ }^{9}$ Najpełniejszej analizie poddała ten problem Irena Gieysztorowa I. Gieysztorowa, Wstęp do demografii staropolskiej, Warszawa 1976, s. 146-161. Nowszą literaturę przedmiotu podsumowuje Krzysztof Boroda. K. Boroda, Kmieć, tan czy profit? Co było podstawą poboru tanowego w XV i XVI wieku?, w: Człowiek wobec miar i czasu w przeszłości, red. P. Guzowski, M. Liedtke, Kraków 2007, s. 152-153.

10 Por. recenzje pierwszego tomu wydanego według pełnych zasad serii, ti. Mazowsza („Kwartalnik Historyczny”, 82, 1975, s. 644-649),
}

względną obfitością źródeł, przydatnych szczególnie w badaniach osadniczych. Są to przede wszystkim rejestry poborowe, i to nie pojedyncze spisy, lecz całe serie. Np. dla niemal każdego powiatu w Wielkopolsce dysponujemy ok. dziesięcioma takimi zestawieniami. Dochodzą do tego wizytacje (po uwzględnieniu tych z początku XVII w. mamy zazwyczaj więcej niż jedną dla każdej parafii), a następnie lustracje, obejmujące wprawdzie tylko dobra królewskie i charakteryzujące się różnym stopniem szczegółowości, ale zawierające więcej informacji o konkretnych miejscowościach niż dwie wspomniane wyżej serie. Korpus można uzupełnić o zachowane w wielkim wyborze księgi grodzkie i ziemskie, akta konsystorskie i kapitulne, urbarze i wiele innych ${ }^{11}$. Dzięki takim zasobom możliwe jest stworzenie rekonstrukcji sieci osadniczej, gdzie informacje pewne i precyzyjne zdecydowanie przeważają nad hipotecznymi i przybliżonymi. W opracowanych dotąd województwach zdarzają się regiony względnie silnie nasycone przypadkami niepewnymi, np. przysiółki na północno-wschodnich rubieżach Mazowsza, lecz nawet tam większość osad zidentyfikowana jest jednoznacznie.

Drugi zabieg to klasyfikacja uzyskanych wyników. Wtłoczenie całego bogactwa poznawanej przeszłości w kilka umownych pojęć i symboli stanowi oczywiście poważne zubożenie rekonstruowanego obrazu. Każdą miejscowość przypisujemy konkretnej kategorii: wieś, miasto, folwark, kuźnica itd. Nie ma tu miejsca na formy pośrednie, mieszane, słabiej rozpoznane. Podobnie z ich wielkością. Wszystkie wsie zostały podzielone na duże i małe, a umowną granicą jest liczba 200 mieszkańców. Tak daleko idące przybliżenie wynika przede wszystkim z bardzo pośredniego charakteru danych. Dla większości osad podstawowym, choć oczywiście nie jedy-

i ostatniego dotąd wydanego („Studia Źródłoznawcze”, 48, 2010, s. 182-185).

11 S. Smolka, 0 przygotowawczych pracach, s. 9-13; K. Chłapowski, Written Sources, w: Historical Atlas of Poland in the $2^{\text {nd }}$ Half of the $16^{\text {th }}$ Century. Voivodeships of Cracow, Sandomierz, Lublin, Sieradz, Łęczyca, Rawa, Płock and Mazovia, ed. M. Słoń, vol. 2, Frankfurt a. Main 2014 (Geschichte Erinnerung Politik. Posener Studien zur Geschichts-, Kultur- und Politikwissenschaft, 6), s. 47-61. 
nym punktem wyjścia do obliczeń jest liczba łanów. $\mathrm{Na}$ jej podstawie oceniana jest liczba gospodarstw kmiecych, mnożona następnie przez szacunkową liczbę osób w takim gospodarstwie, przyjętą dla danego regionu i przynależności własnościowej. Ta ostatnia również jest kategorią bardzo pojemną. Np. wśród dóbr szlacheckich mieści się i półłanek obrabiany osobiście przez swego pana, i fragment potężnego latyfundium magnackiego. Dopiero na tematycznych mapach poglądowych, począwszy od tomu sandomierskiego, wprowadzono wyodrębnienie wielkiej własności. Zróżnicowane były także formy faktycznego sprawowania praw własnościowych. Wśród osad królewskich zobaczymy i te faktycznie zasilające skarb koronny, i praktycznie zawłaszczone przez dzierżawców dobra ${ }^{12}$. Rozróżnienia między nimi nie znajdziemy ani na mapie, ani w indeksie. Redukcję informacji najdobitniej widać przy porównaniu planu okolic Krakowa w skali 1:10 000 i przybliżenia mniej więcej tego samego obszaru w skali 1:125 000, umieszczonym na mapie głównej ${ }^{13}$. Dla innych okolic nie dysponujemy tak precyzyjną rekonstrukcją przestrzenną, co wynika zarówno z zasobu informacyjnego zachowanych źródel, jak i ze stanu badań. Niezależnie od tego klasyfikacja punktów jest niezbędna dla czytelności mapy w przyjętej skali i dla statystycznej analizy danych.

Warto jednocześnie podkreślić umowność zastosowanych na mapie symboli. Osady są obrazowane kółkiem. Najmniejsze, oznaczające małą wieś, mają średnicę ok. $1,5 \mathrm{~mm}$, co przy skali 1:250 000 odpowiada ponad 400 metrom. Niewielka osada mogła zmieścić się na takim obszarze w całości, a zarazem licząca np. 30 gospodarstw ulicówka prawdopodobnie wykraczała poza ten zasięg. Oznaczenie zamku jest kilkakrotnie większe i przypomina budowlę widzianą z boku. W sposób oczywisty nie jest to więc próba odzwierciedlenia ich kształ-

\footnotetext{
12 Np. W. Pałucki, Przynależność własnościowa osad, w: Mazowsze s. 89-90. Por. rozdziały pt. Osadnictwo w kolejnych tomach serii.

13 Województwo krakowskie w drugiej połowie XVI wieku (mapa główna), oprac. kart. E. Rutkowska, J. Rutkowski, w: Województwo krakowskie mapa nr 1; Kraków i okolice $w$ drugiej połowie XVI wieku, oprac J. Laberschek, oprac. kart. E. Rutkowska, mapa nr 6, w: Województwo
} krakowskie. tu, lecz jedynie wskazanie orientacyjnego położenia. Kartografia historyczna nie daje wiernego odbicia przestrzennego dawnych obiektów i nie powinna stwarzać takich pozorów. $Z$ tego właśnie względu ograniczyliśmy dokładność informacji przestrzennej w indeksie do angielskiej edycji dotychczasowych tomów. Przygotowując tę publikację, przenieśliśmy niemal całą treść mapy do przestrzennej bazy danych $(\mathrm{GIS})^{14}$. W indeksie zdecydowaliśmy się odejść od dotychczasowej tradycji, zgodnie z którą określano prostokąt odpowiadający arkuszom map Wojskowego Instytutu Geograficznego (WIG). Zamiast tego posłużyliśmy się współrzędnymi geograficznymi. Aby jednak nie stwarzać pozoru precyzyjnej lokalizacji, ograniczyliśmy przybliżenie do jednej dziesiątej stopnia. Przed podobnym dylematem stajemy w trakcie prac nad aktualnym tomem, dotyczącym Wielkopolski. Dzięki wprowadzeniu informacji źródłowej do arkuszy kalkulacyjnych i ustaleniu umownych przeliczników demograficznych (np. liczba osób przypadająca na łan kmiecy lub rodzinę zagrodniczą) dysponujemy obliczeniami liczby mieszkańców każdej osady z „dokładnością” do jednej osoby. Oczywiście rzeczywista precyzja tych danych jest zupełnie inna i nie można ich publikować w tej postaci. Postanowiliśmy dokonać klasyfikacji wyników, wyznaczając wysokości graniczne. Pojawił się jednak problem ich opisu: jeśli dana kategoria sięgała liczby 100 mieszkańców, następna musiała zaczynać się od 101, co w sposób wręcz nachalny sugerowałoby precyzję tych szacunkowych przecież danych. Prawdopodobnie zrezygnujemy z podawania dolnej granicy poszczególnych klas.

Informację o charakterze treści kartograficznej niesie nie tylko sposób jej prezentacji na mapie, lecz także załączony do niej komentarz. Jest to kolejny, ważny element rzetelności

\footnotetext{
14 P.S. Ell, I.N. Gregory, Adding a New Dimension to Historical Research with G/S, „History and Computing”, 13 (1), 2001, s. 1-6; I.N. Gregory, K.K. Kemp, R. Mostern, Geographical Information and Historical Research: Current Progress and Future Directions, „History and Computing", 13 (1), 2001, s. 2-23, szczeg. 15-17; A.K. Knowles, Emerging Trends in Historical G/S, „Historical Geography”, 33, 2005, s. $9-12$.
} 
rekonstrukcji. Papierowe wydanie mapy praktycznie uniemożliwia opatrzenie każdego symbolu stosownym przypisem. W przypadku dużych arkuszy trudno jest załączyć do nich stosowny wstęp. W omawianej tu serii rolę tę spełniaja osobne tomy, referujące przede wszystkim za stosowaną metodę i uzyskane wyniki. Ważna ich część stanowi wspomniany już wyżej indeks. W znacznej mierze powtarza on treść mapy, uzupełniając ją o niektóre informacje. Nie podaje natomiast nawet względnie precyzyjnego położenia obiektów. Może zarazem stanowić pomost między komentarzem a mapą, jeśli wskazuje konkretne miejsca $\mathrm{w}$ tym pierwszym. Informacji tej brakowało w trzech pierwszych tomach, lecz została uzupełniona dla całości w edycji angielskiej ${ }^{15}$.

Nawet obszerny komentarz nie zastapi jednak w pełni kwintesencji aparatu naukowego: przywołania przy konkretnej informacji jej dokumentacji źródłowej. Wymagałoby to opatrzenia każdego punktu osadniczego obszernym przypisem. W edycji cyfrowej jest to nie tylko możliwe, lecz nawet względnie łatwe. Co więcej, można przywołać nie tylko opis bibliograficzny czy sygnaturę archiwalną z odpisem krótkiego fragmentu, lecz także źródło in extenso, $\mathrm{i}$ to $\mathrm{w}$ postaci faksymile. Tak właśnie ma wyglądać kolejny tom atlasu. Obok tradycyjnej edycji papierowej ukaże się także wirtualna edycja najważniejszej serii źródło- wej, czyli rejestrów poborowych - w postaci przestrzennej bazy danych. Aby zweryfikować podaną na mapie informację o konkretnej miejscowości, użytkownik będzie musiał tylko kliknąć jej symbol. Otworzy się okno z ogólnymi wiadomościami na temat osady, wyborem danych źródłowych ze wspomnianych rejestrów i linkami do cyfrowego obrazu odpowiednich stron rękopisu. W ten sposób autorzy atlasu mogą udokumentować dokonaną przez siebie rekonstrukcję sieci osadniczej ${ }^{16}$.

Kartograf historyczny nie ucieknie przed sprzecznością wskazaną we wstępie do niniejszych materiałów pokonferencyjnych. Wyników dokonanej przez niego rekonstrukcji nie da się w pełni przedstawić na mapie. Rozbieżność między bogactwem badanej rzeczywistości i labiryntem dróg, które prowadzą historyka do jej poznania, a $\mathrm{z}$ natury uproszczonym obrazem kartograficznym można jednak ograniczyć, uporządkować i udokumentować. Zasadnicze znaczenie ma taki wybór przedmiotu badań, dla którego dysponujemy odpowiednią bazą źródłową. Uzyskane wyniki trzeba poddać klasyfikacji mimo nieuniknionej utraty części informacji, jaką pociąga za sobą ta procedura. Następnie należy ją wyczerpująco opisać, aby użytkownik mógł przynajmniej w ogólnych zarysach poznać zastosowaną metodę. Jeśli to możliwe, warto udostępnić mu także wykorzystaną podstawę źródłową.
15 Historical Atlas of Poland, vol. 4, s. 1003-1564.

${ }_{16}$ Atlas historyczny Polski. Rejestry poborowe województwa kaliskiego w XVI w., red. M. Stoń, 2013 (http://atlasfontium.pl/index.php?article =kaliskie, dostęp: 9 czerwca 2015); Atlas historyczny Polski. Rejestry poborowe województwa poznańskiego w XVI w., red. M. Słoń, 2015, (http://atlasfontium.pl/index.php?article=poznanskie, dostęp: 9 czerwca 2015). 


\section{Bibliografia}

Źródła opublikowane

Atlas historyczny Polski. Rejestry poborowe województwa kaliskiego $w X V I$ w., red. M. Słoń, 2013 (http://atlasfontium.pl/index.php?article =kaliskie, dostęp: 9 czerwca 2015).

\section{Literatura przedmiotu}

Boroda K., Kmieć, tan czy profit? Co byto podstawa poboru tanowego w XV i XVI wieku?, w: Cztowiek wobec miar i czasu w przesztości, red. P. Guzowski, M. Liedtke, Kraków 2007, s. $152-170$.

Ell P.S., Gregory I.N., Adding a New Dimension to Historical Research with GIS, „History and Computing", 13 (1), 2001, s. 1-6.

Gieysztorowa I., Wstęp do demografii staropolskiej, Warszawa 1976.

Gregory I.N., Kemp K.K., Mostern R., Geographical Information and Historical Research: Current Progress and Future Directions, „History and Computing", 13 (1), 2001, s. 7-23.

Historical Atlas of Poland in the $2^{\text {nd }}$ Half of the $16^{\text {th }}$ Century. Voivodeships of Cracow, Sandomierz, Lublin, Sieradz, Łęczyca, Rawa, Ptock and Mazovia, ed. M. Słoń, vol. 1-4, Frankfurt a. Main 2014 (Geschichte Erinnerung Politik. Posener Studien zur Geschichts-, Kultur- und Politikwissenschaft, 6).

Knowles A.K., Emerging Trends in Historical GIS, „Historical Geography”, 33, 2005, s. 7-13.

Konopska B., Polskie atlasy historyczne. Koncepcje i realizacje, Warszawa 1994.

Mazowsze $w$ drugiej potowie XVI wieku, red. W. Pałucki, Warszawa 1973 (Atlas historyczny Polski. Mapy szczegółowe XVI wieku, 7) [rec.: KH, 82, 1975, s. 644-649].

Atlas historyczny Polski. Rejestry poborowe województwa poznańskiego wXVI w., red. M. Słoń, 2015 (http://atlasfontium.pl/index.php?article =poznanskie, dostęp: 9 czerwca 2015).

Rutkowski H., Atlas historyczny Polski, w: Towarzystwo Naukowe Warszawskie. Sto lat dziatalności, red. E. Wolniewicz-Pawłowska, W. Zych, Warszawa 2009, s. 115-121.

Smolka S., O przygotowawczych pracach do geografii historycznej Polski, oprac. J. Kurowiak, wstęp M. Filipowicz, „Studia Geohistorica”, 1, 2013, s. 8-13 (edycja pierwotna: Pamiętnik pierwszego Zjazdu Historycznego Polskiego imienia Jana Dtugosza odbytego w Krakowie $w$ czterechsetna rocznice jego śmierci, Kraków 1881 (Scriptores Rerum Polonicarum, 6), s. 133-137).

Wojciechowski S., Województwo lubelskie w drugiej potowie XVI wieku, Warszawa 1966, (Atlas historyczny Polski. Mapy szczegółowe XVI wieku, 3).

Województwo krakowskie w drugiej potowie XVI wieku, red. H. Rutkowski, Warszawa 2008 (Atlas historyczny Polski. Mapy szczegółowe XVI wieku, 1) [rec.: „Studia Źródłoznawcze", 48, 2010, s. 182-185].

Województwo sandomierskie $w$ drugiej potowie XVI wieku, red. W. Pałucki, Warszawa 1993 (Atlas historyczny Polski. Mapy szczegółowe XVI wieku, 2).

Województwo sieradzkie i województwo tęczyckie $w$ drugiej potowie XVI wieku, red. H. Rutkowski, Warszawa 1998 (Atlas historyczny Polski. Mapy szczegółowe XVI wieku, 5). 


\section{The Reconstruction of the Settlement Network in "Historical Atlas of Poland. Detailed Maps of $16^{\text {th }}$ Century"}

\section{Summary}

One of the major research objectives of the series "Historical Atlas of Poland. Detailed Maps of $16^{\text {th }}$ cent." is to reconstruct the settlement network. The present text analyzes the methods by means of which that information was presented in a cartographic form. Within the 60 years of studies, the existence of more than 20000 localities in the $16^{\text {th }}$ century was verified, their localization, name, character (e.g. a town, a village, a milling settlement), size, kind of ownership, central functions and administrative association were established. Those data frequently contain a number of variants (e.g. varieties of names, mixed ownership, changes in time) hence they are approximate and hypothetical. Presenting such a material on a map was possible thanks to the fact that the analysis included the period of relatively good source documentation, classification of the obtained results and an abundant commentary. Reconstruction of the settlement networks in the current works is presented not only in the form of a map and a developed index but also as a spatial database linked to the edition of the most important category of sources. This makes it possible to present the richer content and better documentation of the adopted views.

Słowa kluczowe: kartografia historyczna, sieć osadnicza, Polska, epoka nowożytna

Keywords: historical cartography, settlement network, Poland, Early Modern Times

dr hab. Marek Stoń - profesor w Instytucie Historii im. Tadeusza Manteuffla Polskiej Akademii Nauk, kierownik Zakładu Atlasu Historycznego.

Zainteresowania badawcze: dzieje miast i religijności w średniowieczu, geografia i kartografia historyczna (e-mail: marek.slon@wp.pl) 